Western North American Naturalist 69(3), (C) 2009, pp. 403-406

\title{
A HISTOLOGICAL STUDY OF THE PRIMARY GONADAL TISSUE OF AN ANTLERLESS BUCK MULE DEER (ODOCOILEUS HEMIONUS)
}

\author{
Richard Heckmann ${ }^{1}$
}

\begin{abstract}
An antlerless mule deer (Odocoileus hemionus) was collected on 2 December 1992 from an established Oak Creek mule deer herd 2 miles north of Oak City, Utah (Utah Wildlife Receipt \#027604). Upon examination, the animal had prominent male genitalia with hair rubbed off from the pedicle part of the skull. Tissue examination revealed active spermatogenesis and viable sperm in the lumen of the epididymis and testis. Antlerless male deer have been reported previously in this area, but this is the first histological study of the abnormal deer. Lack of antlers would be advantageous for male deer during the hunting season because most western states limit deer harvest to antlered bucks.
\end{abstract}

Key words: spermatogenesis, antlerless male deer, Odocoileus hemionus.

On 2 December 1992, a dead mule deer (Odocoileus hemionus) was brought to the Monte L. Bean Life Science Museum at Brigham Young University (BYU), Provo, Utah. A conservation officer with the Utah Division of Wildlife Resources (UDWR) had harvested it 2 miles north of Oak City, Millard County, Utah (Utah Wildlife Receipt \#027604). The animal weighed 220 pounds $(99.8 \mathrm{~kg}$ ) after evisceration (field-dressing) - large for a mule deer (Robinette et al. 1977, Stewart and Hayes 1999). The conservation officer thought the deer peculiar as he watched it trailing a doe and "acting like a buck." It had a definite swollen neck but no antlers, and upon examination testicles were prominent (Fig. 1).

The goals of this project were to (1) histologically examine the testes and epididymis of the mule deer to evaluate the reproductive potential of an antlerless male mule deer and (2) comment on the evolutionary significance of an antlerless male deer in an established deer herd. This is the first published record of histological evaluation of gonadal tissue from an antlerless male mule deer. Gross anatomy of the deer was recorded, and the skin and skull were prepared and deposited in the M.L. Bean Life Science Museum (\#13331).

Sections of both the epididymis and testis were fixed in $10 \%$ buffered formalin. Following dehydration and blocking, standard methods (Bancroft and Gamble 2001, Kienan 2002) were used to section the paraffin-blocked samples. The tissue was cut at 4-6 $\mu \mathrm{m}$, and after mounting on glass slides, one batch was stained with hematoxylin and eosin (H\&E) and another with Mallories trichrome stain (Galigher and Kozloff 1971). A Zeiss LSM laser-equipped compound light microscope was used to examine the prepared glass slides, and representative pictures were taken at varying magnifications with a digital camera.

Gross examination of the carcass revealed a swollen neck and no visible antlers. Moreover, the skull had no noticeable pedicles (Fig. 2). Hair had been rubbed off the pedicle region of the head, and there was visible hair loss inside the hind legs, indicative of reproductive activity. A gelatinous-type injury to the skin was evident inside the hind legs where the hair had been rubbed off (Fig. 1).

Tissue from the testis and epididymis stained with hematoxylin and eosin ( $\mathrm{H} \& \mathrm{E})$ exhibited evidence of active spermatogenesis (Figs. 3, 4). All stages of spermatogenesis, spermatogonia to spermatids, were visible with numerous mature sperm in the lumen of the epididymis (Fig. 4). Slides stained with Mallories trichrome displayed similar results. No pathological tissue was observed. The lumen of the stereociliated epididymis was packed with mature sperm (Fig. 4).

During the mating season, male mule deer use their antlers in intrasexual contests to

${ }^{1}$ Brigham Young University, Department of Biology, A-242 CLFB, Provo, UT 84602-5255. E-mail: richard_heckmann@byu.edu 


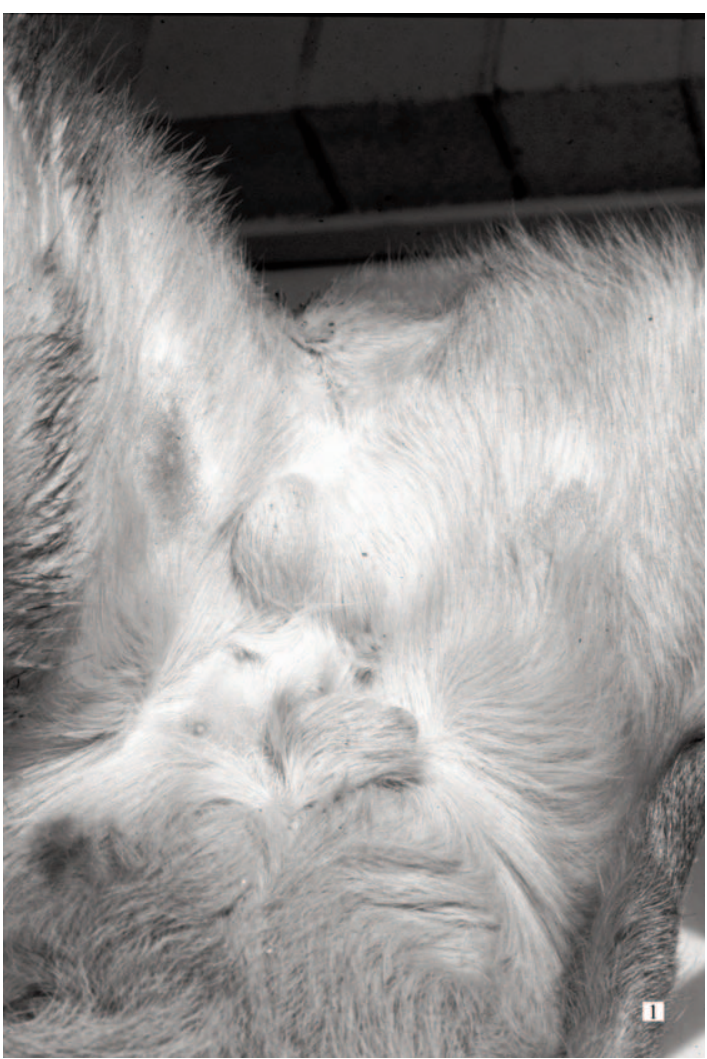

Fig. 1. The external male genitalia, penis and testicles, of the antlerless male mule deer (Odocoileus hemionus). Note rubbing with an obvious gelatinous sore on the inside of the hind legs, indicative of reproductive activity.

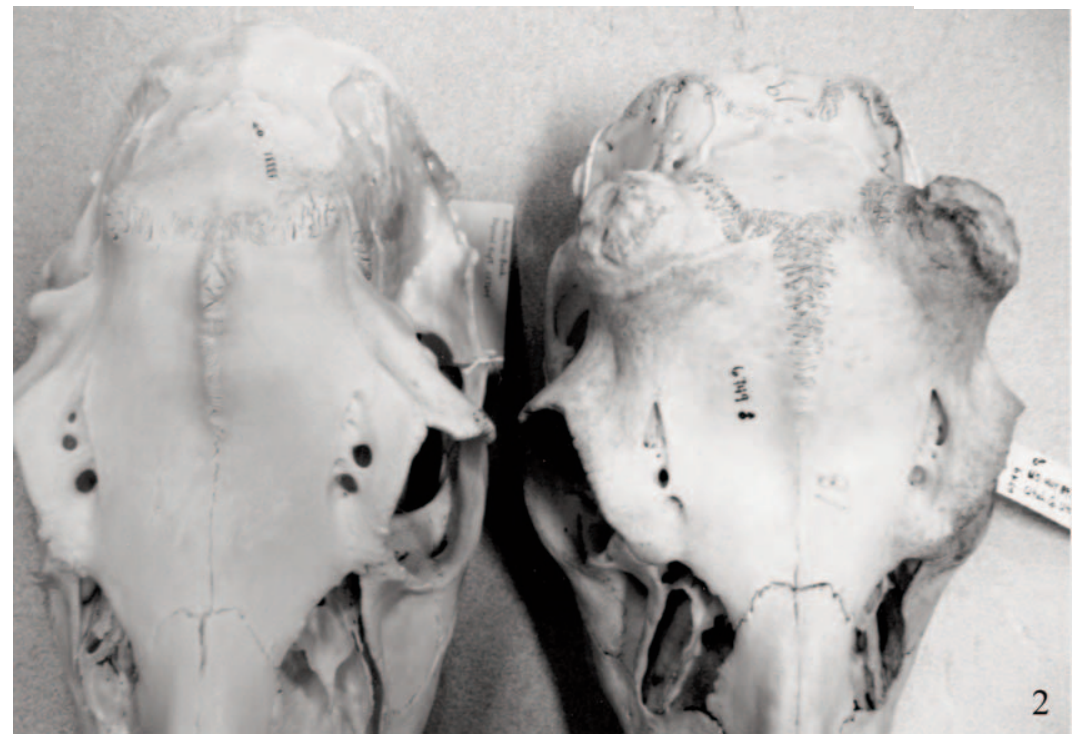

Fig. 2. Skull (left) of the antlerless male mule deer (Odocoileus hemionus) compared with a skull (right) from a normal male mule deer. Note prominent pedicles for the normal deer and absence of pedicles for the antlerless deer. 


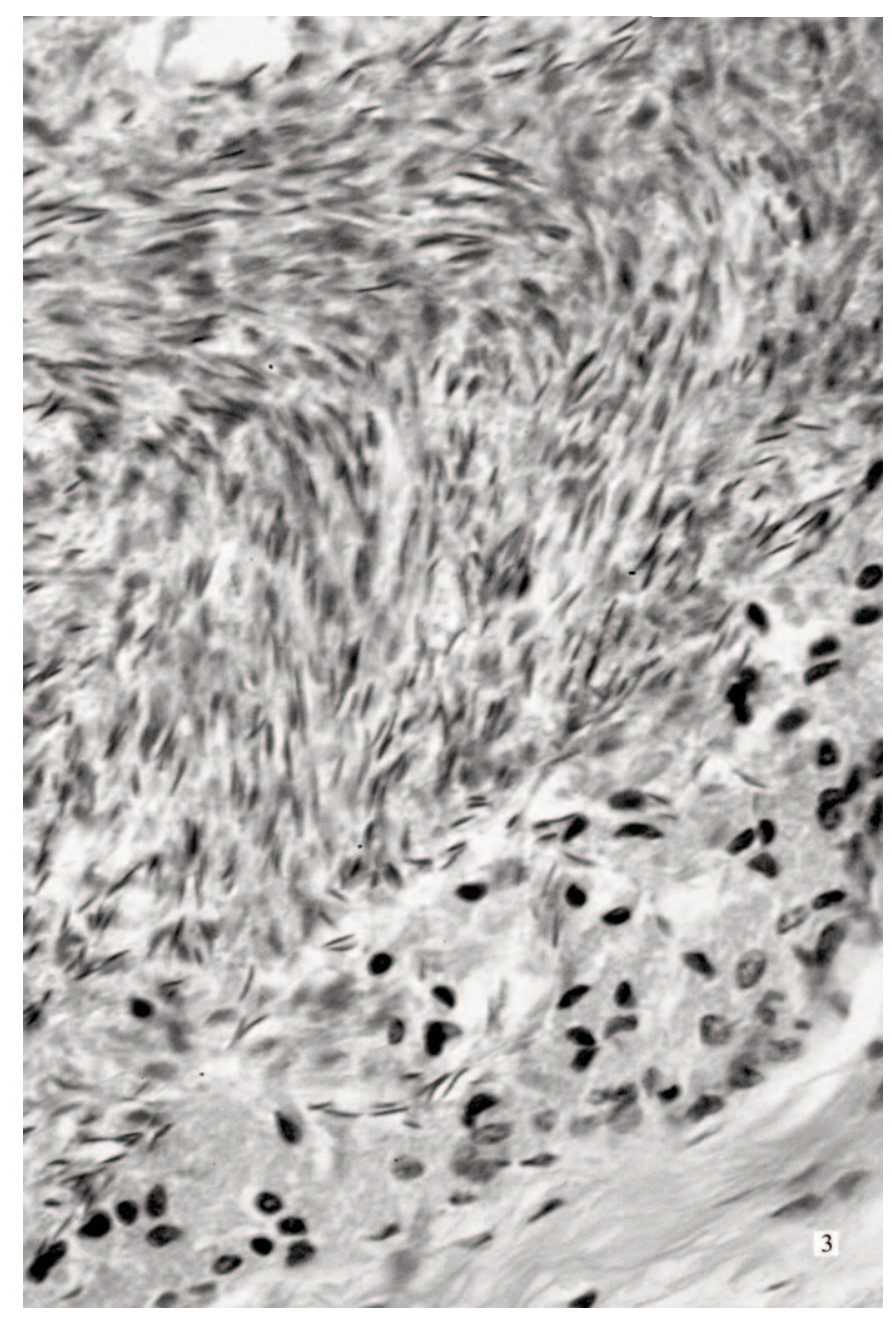

Fig. 3. Section of the testis of the antlerless male mule deer (Odocoileus hemionus). Note the stages of spermatogenesis occurring in the outer epithelial layer with mature sperm in the lumen. 430X.

establish dominance for access to receptive females, and for display to attract mates (Nellis 1968, Stewart and Hayes 1999). Bucks mark their territory by making scrapes on the land with their hooves and by removing bark from trees with their antlers, leaving marks called "buck rubs" (Chase and Jenkins 1962, Mansell 1968). Sexually mature males without antlers would likely have reduced fitness relative to antlered males when male densities are high. However, antlerless male deer may be at an advantage in areas where hunting regulations limit deer harvest to antlered bucks and selective behavior by hunters focuses on antler size as a criterion for harvest. Antlerless males may have lower mortality compared to antlered males, and they may benefit from a greatly reduced density of adult males during the rut as a consequence of mortality due to hunting.

The author wishes to acknowledge Dr. H. Duane Smith and Wesley "Skip" Skidmore, M.L. Bean Life Science Museum, Brigham Young University; Dr. Jerran T. Flinders and Dr. Hal L. Black, Biology Department, Brigham Young University; and Darrell McMahon, Utah Division of Wildlife Resources, who provided information and samples from the antlerless male mule deer. The histology laboratory at the Utah Valley Regional Medical Center in Provo, Utah, prepared slides for the author. 


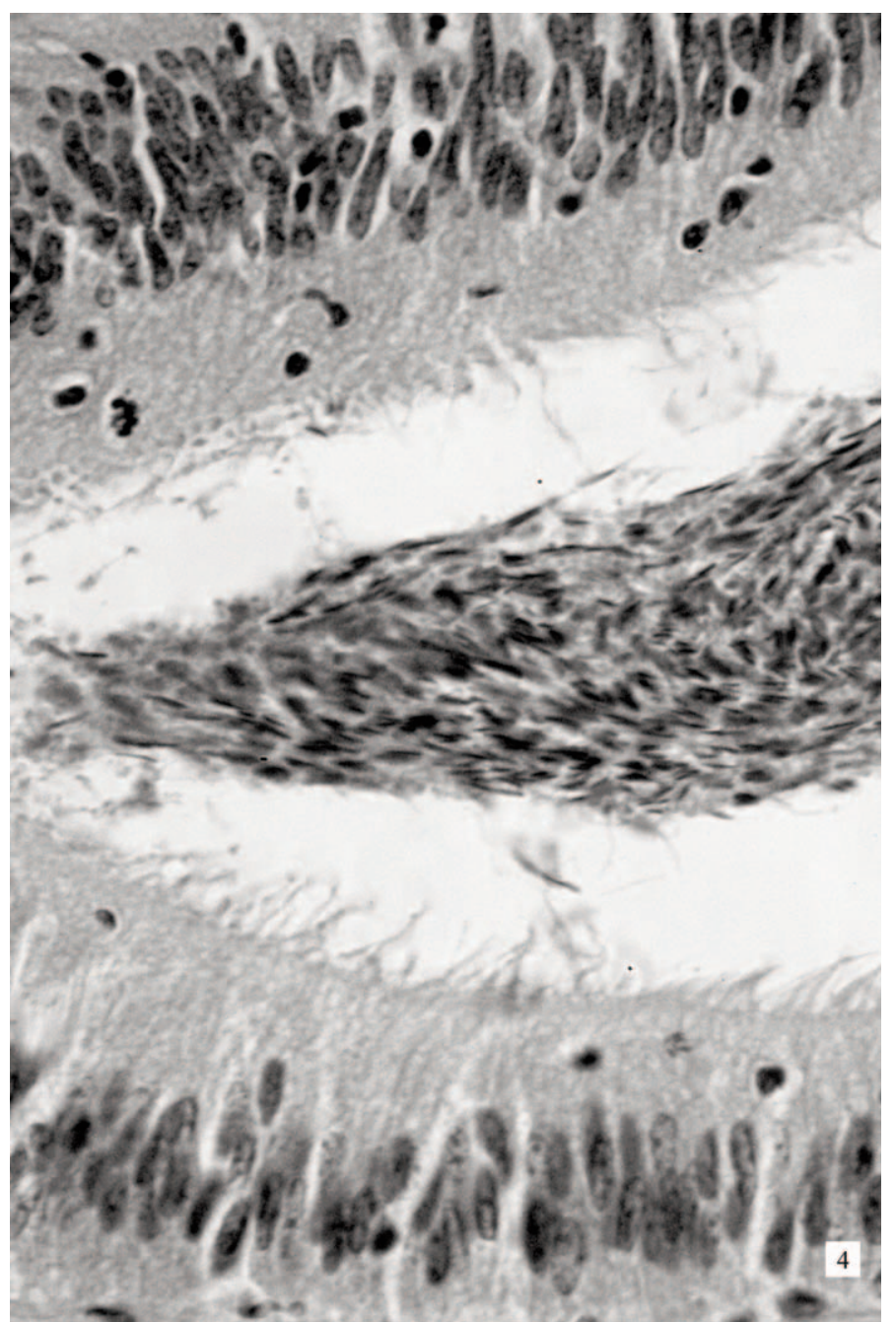

Fig. 4. Epididymis of the antlerless male mule deer (Odocoileus hemionus). Note the stereociliated epithelial lining and the sperm in the lumen of the duct. H\&E stain. 430X.

\section{Literature Cited}

BANCROFT, J.D., AND M. GAMBLE. 2001. Theory and practice of histological techniques. 5th edition. Churchill Livingstone Publishers, Edingburough, United Kingdom.

Chase, W.W., and D.H. Jenkins. 1962. Productivity of the George Reserve deer herd. Proceedings of the National White-tailed Deer Disease Symposium 1:78-86.

Galigher, A.E., AND E.N. Kozloff. 1971. Essentials of practical microtechnique. 2nd edition. Lea and Febiger, Philadelphia, PA. 531 pp.

Kienan, J.A. 2002. Histological and histochemical methods; theory and practice. Churchill Livingstone, Edingburough, U.K.

Mansell, W.D. 1968. The breeding and subsequent fawning season in the Bruce Peninsula deer herd. Ontario Fish Wildlife Review 7(1-2):15-22.
NeLLis, C.H. 1968. Productivity of mule deer on the National Bison Range. Montana. Journal of Wildlife Management 32(2):344-349.

Robinette, W.L., N.V. Hancock, and D.A. Jones. 1977. The Oak Creek Mule Deer Herd in Utah. Publication No 77-15, Utah Division of Wildlife Resources, Salt Lake City, UT. 148 pp.

Stewart, R., and F.H. Hayes. 1999. Mule deer (Odocoileus hemionus). Wildlife Notebook Series No. 13, Utah Division of Wildlife Resources, Salt Lake City, UT.

Received 24 October 2008 Accepted 27 April 2009 